\title{
A DÉL-DUNÁNTÚLI RÉGIÓ KÖRNYEZETI ÁLLAPOTA A GAZDASÁGFEJLESZTÉSI STRATÉGIA EGYIK ELEME
}

(State of Environment in the Southern Transdanubian Region Is an Element of the Economic Development Strategy)

\section{FODOR ISTVÁN}

\section{Bevezetố}

A gazdaság átalakulása, a szerkezetváltás, a piacgazdaság kiépítése, a nyilvánosság súlyának növekedése a döntési folyamatokban a gazdaságnak egy teljesen újfajta viszonyulását formálja a környezethez mint erőforráshoz éppen úgy, mint az egészséges életfeltételek megteremtéséért és fenntartásáért küzdỗ környezetvédelmi politikához.

A természeti környezet ma már egyre szigorúbban üt vissza pl. profitvesztéssel azoknál a gazdálkodó egységeknél, amelyek a megújuló természeti erôforrásokat továbbra is értékükön alul szeretnék hasznosítani. Az új tulajdonosi szemlélet érvényesülésével mérséklôdhetnek a környezeti károk. A magántulajdon ugyanis az önálló gazdálkodás és szabad hozamnyerés mellett a vagyon hosszabb távú állapotáért és a környezet minōségéért viselt szigorúbb felelôsséget jelent. Másrészt a környezeti konfliktusoknak a teljes nyilvánosság melletti kezelése jelentôs mértékben megnöveli az önkormányzatok felelôsségét a környezetpolitikában (Fodor 1. -Orosz T. 1994).

A környezetvédelem iránti érzékenység ezért várhatóan legmarkánsabban a településeken és a régiókban bontakozik $\mathrm{ki}$. Az új regionális folyamatok máris változásokat involválnak a környezeti terhelés jellegének és földrajzi eloszlásának megváltozásában (Enyedi Gy. 1992). Rögvest adódik a kérdés: hatékonyak-e és mennyire gyorsak ezek a változások? Elemzéseink azt mutatják, hogy egy virulens, optimista környezeti jövökép felvázolására, illetve annak megvalósulására belátható idốn belül kevés esélyünk van. Az eddigi változások ma még inkább Magyarország ipari régióiban érhetôk tetten, ott is elsôsorban a hagyományos nehézipari központok térségében, ahol a környezetszennyezés csökkenése inkább köszönhetố a korszeruitlen ipari létesítmények csôdjének, semmint azok korszerúsítésének. Ez a folyamat egyelốre nem kedvez annak, hogy lefékezôdjék az ország környezetminõségének romlása. A kevésbé szennyezett régiókban azonban a környezet állapota markáns eleme lehet egy versenyképes gazdaságfejlesztési stratégia megalapozásának (Faragó L. 1994). 


\section{A dél-dunántúli régió környezeti állapota}

Dél-Dunántúl néhány iparosodott térségét leszámítva a régió jelentốs részének környezeti állapotát éppen az ipari fejlổdés megkésettsége, illetve elmaradása kímélte meg a súlyos ökológiai degradációtól. Ezt igazolja az is, hogy - a Komló-Pécs-Beremend ipari térség kivételével - a régió környezetének minôsége az. országos helyzetképhez viszonyítva sok tekintetben kedvezố képet mutat. Ez serkentôen hathat a magánszféra új gazdaságfejlesztési kezdeményezéseire, a szerkezetváltás sikeres megoldására, a térség revitalizációjára is. Környezeti konfliktusoktól azonban a Dél-Dunántúl sem mentes, közülük számos már ma sem oldható meg helyi erõforrásokból. A jelentõsebb környezeti problémák kezeléséhez regionális forrásokra lenne szükség, ezeknek hiján azonban a konfliktusok feloldása itt is országos finanszírozásra vár (pl. a régióban keletkezõ, illetve itt elhelyezett veszélyes hulladékok kezelése, ártalmatlanítása).

\section{Levegôminôség}

A térség levegõminôsége - az immissziós érékek alapján - néhány kritikus pontot leszámítva elfogadhatónak minốsíthetô; az országos átlagnál kedvezổbb. A szennyezés e térségben elsôsorban ipari, közlekedési és kommunális eredetũ, de szerepet játszanak a mezõgazdasági termelésbổ származó szennyezôanyagok is. Az emberi kömyezet szempontjából elổnyös a térség szélsõségektổl mentes, kiegyensúlyozott éghajlata, a gazdag erdôállomány, az aprófalvas településszerkezet. Ez utóbbi alól kivételt képez a pécsi agglomeráció térsége, valamint a Balaton déli partvidéke, amelyek a levegổminôség szempontjából erôsen terhelt térségek. A Komló-Pécs-Beremend tengelyt az ipari eredetũ szennyezỏanyagok terhelik katasztrofálisan, a Balaton déli partján pedig a közlekedéssel járó környezetszennyezés okoz súlyos gondokat. Megállapításainkat alátámasztja a régió légterét szennyezõ pontforrások és telephelyek térbeli elhelyezkedésének alakulása is. Az 1990 elsô negyedévi állapotnak megfelelôen a régió pontforrásainak több mint 20\%-a Pécs térségében volt, míg az összesnek $78 \%$-a a városokban található. A pontforrásoknak csupán $22 \%$-a szennyezte a levegốt községekben.

A légköri kén- és oxidált nitrogénvegyületek leülepedett mennyiségeinek térbeli vizsgálata is azt mutatja, hogy a dél-dunántúli régió szennyezettsége a pécsi ipari agglomeráció kivételével az országos átlag körül, vagy az alatt változik. A légköri kénvegyületek leülepedett mennyisége $2,0-2,5 \mathrm{~g} \cdot \mathrm{m}^{-2} \cdot \mathrm{é}^{-1} \mathrm{között} \mathrm{változik.} \mathrm{Pécsett} \mathrm{eléri,} \mathrm{sỗt}$ meghaladja a $3,0 \mathrm{~g} \cdot \mathrm{m}^{-2} \cdot e^{-1}$ értéket. Az oxidált nitrogénvegyületek nyugatról kelet felé csökkenó értéket mutatnak $1,1-0,9 \mathrm{~g} \cdot \mathrm{m}^{-2} \cdot$ év $^{-1}$ értékek szerint.

A közlekedésbôll eredô légszennyezés a legnagyobb veszély, mert mértéke rohamosan növekszik a dél-dunántúli régióban is. 1980 és 1990 között a gépjármũforgalom mintegy $60 \%$-kal, a közlekedési emisszió nagysága pedig $57 \%$-kal növekedett. A kibocsátott 
fôbb szennyezóanyagok 1990-ben: szénmonoxid, szénhidrogének, nitrogénoxidok. E három komponens adja a gépjármũforgalomból eredõ légszennyezés 97-98\%-át. A trend veszélyeit jól mutatja be az 1 . ábra.

\section{1. ÁBRA}

Zalaegerszeg levegôminôségét jellemzô trendek az OKI adatai alapján

(Trends in the quality of air in Zalaegerszeg, by the data of $O K D$ )

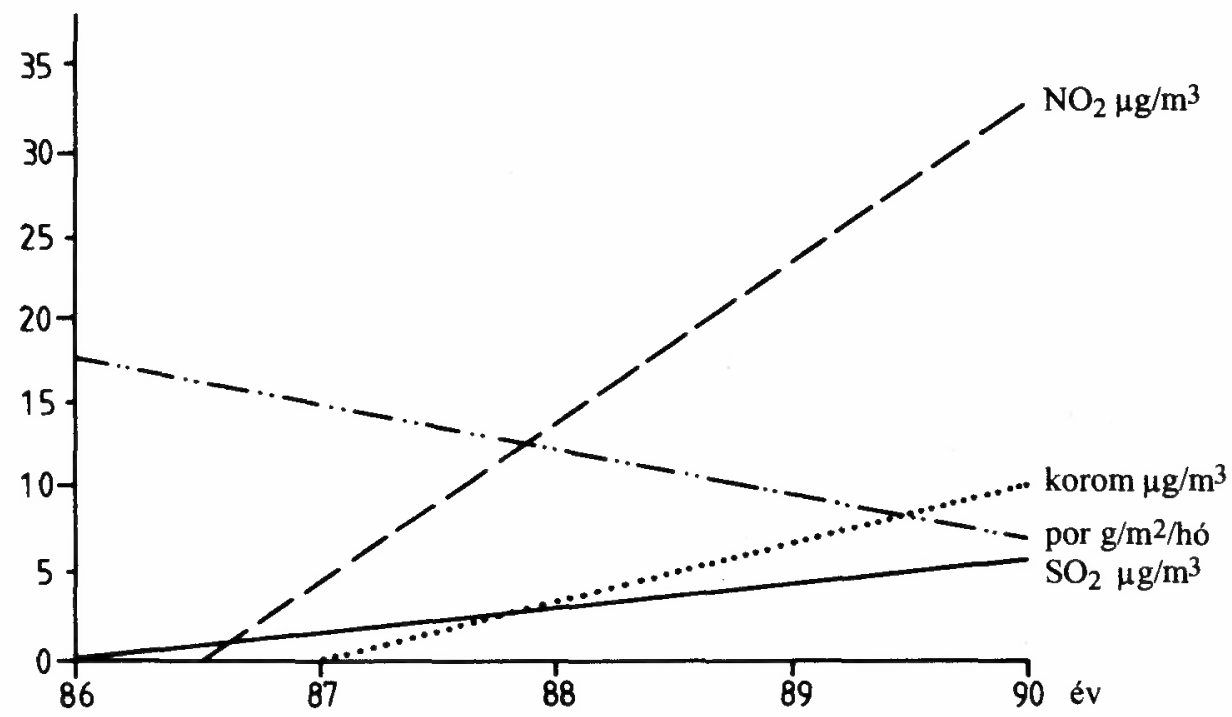

A Környezetvédelmi és Területfejlesztési Minisztérium legújabb értékelései (1994) is alátámasztják a régió légtere környezeti állapotának minôsítését. Ennek alapján szennyezett levegôjuũ települések Pécs $\left(\mathrm{NO}_{2}, \mathrm{SO}_{2}\right.$, por), Zalaegerszeg $\left(\mathrm{NO}_{2}\right.$, por) és Nagykanizsa $\left(\mathrm{NO}_{2}\right)$. Ezeken a településeken az $\mathrm{NO}_{2}$ és $\mathrm{SO}_{2}$ szennyezôanyagok koncentrációja a 24 órára vonatkozó levegổminôségi határértéket a mérési idôszak $10 \%$-ánál, por esetén pedig 30\%-ánál hosszabb idốtartamban meghaladta. Mérsékelten szennyezett a régió 21 településének, valamint a Balaton partvidékének légtere. Ez azt jelenti, hogy a 24 órára érvényes levegổminôségi határértékek túllépése $\mathrm{SO}_{2}$ és $\mathrm{NO}_{2}$ esetében $10 \%$ alatt maradt, a por esetében azonban ez a határérték túllépés még mindig 10-30\% között ingadozott. 
Fodor István: A dél-dunántúli régió környezeti állapota a gazdaságfejlesztési stratégia egyik eleme. Tér és Társadalom, 8. 1994. 1-2. 129-142. p.

A vizkészletek készlet-igény egyensúlya

A dél-dunántúli régió vízkészletei jelentôsek, az igények koncentrálódása azonban jelentôs eltéréseket mutat a készletek helyéhez viszonyítva. A Dél-Dunántúlon három olyan térség alakult ki, ahol a vízigények mennyisége és minôsége megközelítette, illetve meghaladta a természetes vízkészletet. A régió délkeleti részében a pécsi ipari agglomeráció folyamatosan növekedõ vízigényét a Dunával összekötött regionális vezetékkel lehet kielégíteni. A másik központ Kaposvár térsége, a harmadik pedig a Balaton déli partjának üdülõövezete. Pécs vízellátási gondjai ipari vízigényének révén érthetốek. A Balaton esetében is aligha beszélhetünk természetes hasznosítható készletrổ, mert a területhasználati (nagyrészt üdülési) igények miatt történt tószabályozás, a maximális és a minimális vízszinttartási kötelezettség a vízfelhasználási lehetôségeket jelentôsen csökkentette. Ma a Balaton és a Dunántúli-középhegység kiemelt jelentôségũ vízgazdálkodăsi kutatási terület, ahol a bányászat vízkiemelésének változása folyamatosan új helyzetet teremt, és az északi vízgyũjtônn bekövetkezổ változások módosítják a déli part vízkészlet-gazdálkodási helyzetét is.

Az utóbbi időben ezek a folyamatok irányították Baranya és Somogy megye vezetốinek figyelmét a dél-dunántúli régión belül, elsôsorban a Dráva mentén található jelentốs felszíni és felszín alatti készletekre. Ez a vízkészlet a vízfelhasználási igényekhez képest korlátlannak tekinthetó. Átmeneti zavarokat a duzzasztóterek feltöltésekor lehet tapasztalni, mivel ökológiai okokból lényeges szerepe van a minden idốben továbbengedendõ legkisebb vízhozamnak. Pontos meghatározására ma is folynak a kutatások; biztosítására csak nemzetközi megállapodásokkal van lehetôség.

A feiszín alatti vízkészleteknél a talajvíz elszennyezôdése miatt a réteg- és karsztvizek fokozottabb igénybevételére van szükség. A készletigény-egyensúly a régió nyugati térségében még nem veszélyeztetett, ellenben délkeleti részén - különösen a pécsi iparvidék térségében - az egyensúly megbomlását az állandóan növekvô depressziók jeizik.

A mennyiségi készletek mellett az igazi gondot a vízminõség jelenti. A felszín alatti vizkészletek szempontjából nagy veszteség az elsõ vízadóréteg elszennyezôdése. A felszíni vízfolyások szintén súlyos veszélynek vannak kitéve, többek között a közmũolló foly amatos tágulásának következtében.

A régióban a korábbi mezõgazdasági nagyüzemek környezetszennyezố hatása fõleg a hígtrágya nem megfelelõ tárolása miatt jelentkezik napjainkban is. A kezdetben elõszeretettel alkalmazott vízlemosásos tartástechnológiák alkalmazása a 80 -as évek végére háttérbe szorult. A jelentkezõ környezeti ártalmak miatt több jelentốs szakosított állattartó telep megszüntetésére került sor, elsôsorban a kiemelt vízminôségvédelmi területeken. Ezek késleltetett károsító hatásával azonban még hosszú ideig számolni kell.

Az intenzív mezõgazdasági mũvelésũ területek diffúz szennyezô hatása is érzékelhetố, amely elsõsorban a viszonylag magas mũtrágya-felhasználásra vezethetố vissza. Bár napjainkra ez igen jelentôsen csökkent, a szennyezés hatásával ugyancsak hosszú ideig 
számolni kell. A szerves trágyával trágyázott területek korábbi csökkenését a növekvố mútrágya árak állították meg. Az 1990-es évek elejétôl a tendenciák kedvezõ változása figyelhetố meg.

A Balaton déli vízgyũjtỗjén a mezõgazdasági nagyüzemek áttértek a mũtrágyák szuszpenzió formájában történố kijuttatására, ami a hatóanyagok kedvezőbb hasznosulási arányát, a diffúz szennyezések mértékének csökkenését eredményezte.

A felszíni vizek terhelésének változását elemezve és összehasonlítva az 1985. és 1990. évi szennyezõ anyag terheléseket, kitünik, hogy a KOIK és az olaj-, zsírterhelés a vizsgált öt év során jelentôsen csökkent.

E kedvezõ jelenségek a környezetvédelmi beruházásoknak köszönhetốk. Ugyanakkor az összes oldott anyag és az ammónia-terhelés változásának trendjei nem ilyen kedvezõek, inkább stagnálást mutatnak, sổt több területen romlást.

Általános tendencia a környezetvédelmi bírságok nagyságának erốteljes csökkenése. A régióban kivetett szennyvízbírságok összege 1980-tól 1989-ig 50\%-kal csökkent. Figyelembe véve az elbírálások szigorodását is, ez a tendencia a régió szennyvízterhelésének csökkenésére utal. Ennek megítélését azonban óvatosan kell kezelni, miután a szennyező folyamat long term hatású, lényeges javulás hosszú ideig nem várható. Az ipari térségben jelentkezõ környezeti konfliktusok alapján az ipari üzemek szennyvízbírságai minden esetben magasabbak, mint az agrár jelleget mutató térségekben. Baranya megyében az ipari üzemek szennyvízbírsága minden esetben meghaladta a kommunális szennyvíztisztító telepek bírságainak összegét. Legmarkánsabban a mezôgazdasági üzemek szennyvízbírsága csökkent a régióban, több mint $90 \%$-kal. Ennek összetevôi sokfélék. A gazdasági szabályozók mellett kedvezố jelenségnek tekintjük, hogy egy környezetkímélổbb, a természeti környezettel szemben kevésbé agresszív mezõgazdasági termelés van kialakulóban.

\section{Vizellátás}

A régió településeinek vízellâtása meglehetổsen heterogén képet mutat. Míg Somogy megye területén 221 település vízmüvel ellátott, és csupán 10 településen találkozunk átmeneti módon történõ ellátással, addig az erõsebben iparosodott Baranya megye 297 településébôl 1992 végén még 118 nem rendelkezett vízművel. Ezek aprófalvas települések, de figyelmeztetô, hogy 50000 fổ számára az egészséges ivóvíz csak korlátozott mennyiségben áll rendelkezésre (tartálykocsis, tasakos vízellátás). Ennél Zala megye helyzete is jobb, ahol 1992-ben 256 település közül ,,csupán” 18 nem rendelkezett vezetékes ivóvízzel. E tekintetben Tolna megye helyzete a legjobb, ahol 1992-ben már mind a 108 település közmũves ivóvízzel ellátott. Ugyanebben a megyében a csatornázottság viszont alig 30\%-os. 
Az önkormányzatok szerepének, hatáskörének - a rendszerváltozás óta bekövetkezett - megnövekedése rövid idôn belül (1989-1992) kedvezõ változást eredményezett a környezetvédelem területén. Jelentổsen felgyorsult pl. a települések egészséges ivóvizzel való ellátása. Így a régióban jelentõsen csökkent a közegészségügyi szempontból veszélyeztetett települések száma. Ennek adatait mutatja be az 1. táblázat.

\section{TÁBLÁZAT}

A közegészségügyi szempontból veszélyeztetett települések

(Settlements endangered from health aspects)

\begin{tabular}{lrr}
\hline Megnevezés & 1989 & 1992 \\
\hline Baranya & 187 & 89 \\
Somogy & 57 & 20 \\
Tolna & 21 & 1 \\
Zala & 56 & 20 \\
\hline Régió összesen & 321 & 130 \\
\hline Ország összesen & 725 & 243 \\
\hline
\end{tabular}

Forrás: saját számítás.

A nagymértékũ vízhálózat építéssel azonban nem tartott és ma sem tart lépést a csatornahálózat kiépítése a településeken. A régió településeinek lakásszámra vetített ellátottsági mutatóit a 2. ábrán követhetjük nyomon.

Jól látható, hogy a régió városi lakásainak több mint $50 \%$-a csatornahálózattal ellátott, míg a községeknél ez az arány messze $10 \%$ alatt marad. Ezzel összefüggésben a vezetékes vízzel ellátott, de nem csatornázott lakások szennyvize a talajt, ezen keresztül a talajvizet terheli, szennyezi. A több évtizedes folyamat következménye, hogy regionálisan elszennyezõdöttnek tekinthetõ a régió talajvízkészlete.

A régió ipari vízellátása nagyobb torzulásokat mutat. A térség ipari vízfogyasztásának jelentốs hányadát az iparosodottabb, de súlyos vízhiánnyal küszködố Baranya megye használta fel. A környezeti konfliktust fokozta, hogy a vízigényes ipar zöme a vízben különösen szegény megyeszékhely, Pécs körzetébe települt.

A mezốgazdasági célú vízfelhasználás két felhasználási típusra bontható. A mezôgazdasági nagyüzemek telephelyeinek vízfelhasználása nagyrészt az állattartó telepek ellátását szolgálja. Jóval kisebb vízigényt jelent a szociális jellegũ és a járulékos ipari tevékenység. A vízfelhasználás bázisául elsôsorban a rétegvízkészletekre telepített, saját tulajdonú kutak szolgálnak. A fố vízfogyasztó helynek számító állattartó telepeknél a 
Fodor István: A dél-dunántúli régió környezeti állapota a gazdaságfejlesztési stratégia egyik eleme.

Tér és Társadalom, 8. 1994. 1-2. 129-142. p.

\section{2. ÁBRA}

A régió közcsatornával való ellátottsága \%-ban kifejezve

(Provision with public sewerage in the region in per cent [1992])

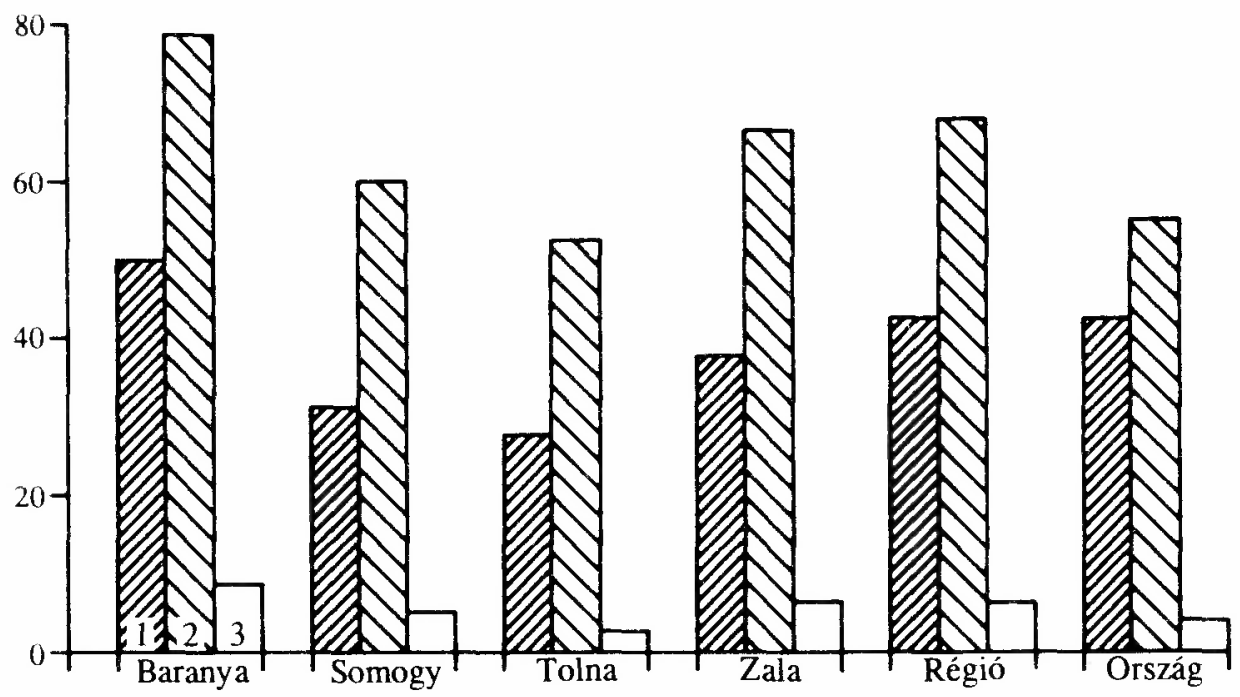

Jelmagyarázat: 1 - összes, 2 - városok, 3 - községek.

technológiai vízigény lényegesen nagyobb hányadot tesz $\mathrm{ki}$ az itatóvíznél, pedig a minôségi kívánalom alapján arra a kevésbé ,,értékes" vízfajták (talajvíz, felszíni viz) is alkalmasak lennének.

\section{Zaj okozta konfliktushelyzetek}

A zaj káros hatása leginkább a közlekedésben és az iparban okoz konfliktust. A Balaton-parti lakó- és üdülökörzetben a kedvezôttlen zajhatás fokozottan érvényesül, amely ellen az utólagos védekezés nem arányosan hatékony a ráforditásokkal (forgalomés munkaszervezési intézkedések). A zajártalmakat leghatékonyabban már az új létesítmények tervezése során lehet kiküszöbölni. 
Fodor István: A dél-dunántúli régió környezeti állapota a gazdaságfejlesztési stratégia egyik eleme.

Tér és Társadalom, 8. 1994. 1-2. 129-142. p.

\section{A hulladék}

A termelési és fogyasztási folyamatok velejárója a hulladék képzôdése. A termékek elôállításából, a fogyasztásból származó szilárd és folyékony hulladékok keletkezése összetett környezetvédelmi probléma, és a gazdaságilag fejlett országokban is a legsúlyosabb gondok okozója.

A nem hasznosított hulladékok elhelyezése nagy és értékes földterületeket foglal el. A nem megfelelôen kezelt, nem ártalmatlanított hulladék veszélyezteti a környezet elemeinek tisztaságát - többnyire szennyezi a talajt, a talajvizet, a felszíni vízfolyásokat, a levegốt. Hatása tájromboló, településegészségügyi és esztétikai szempontból kedvezõtlen.

A hulladék súlyos konfliktlisok forrása a településeken, mert többnyire megoldatlan a kezelése. Dél-Dunántúl 4 megyéjében 2,2 millió $\mathrm{m}^{3}$ települési szilárd hulladék keletkezik évente. A régióban csupán néhány kiemelt településen tekinthetó megoldottnak a kommunális hulladék összegyũjtése, lerakása vagy ártalmatlanítása (pl. a Balaton déli partja). A városok és községek ellátottsága közötti óriási különbség figyelhetố meg a 3. ábrán. A szemét rendszeres, pormentes gyũjtése, elszállítása higiénés környezetegészségügyi feladat is, amely az önkormányzatok felelổsségét tovább növeli.

\section{3. ÁBRA}

A régió szemétszállításba bekapcsolt lakásainak aránya \%-ban kifejezve (1992)

(Rate of flats with waste transportation service in the region per cent [1992])

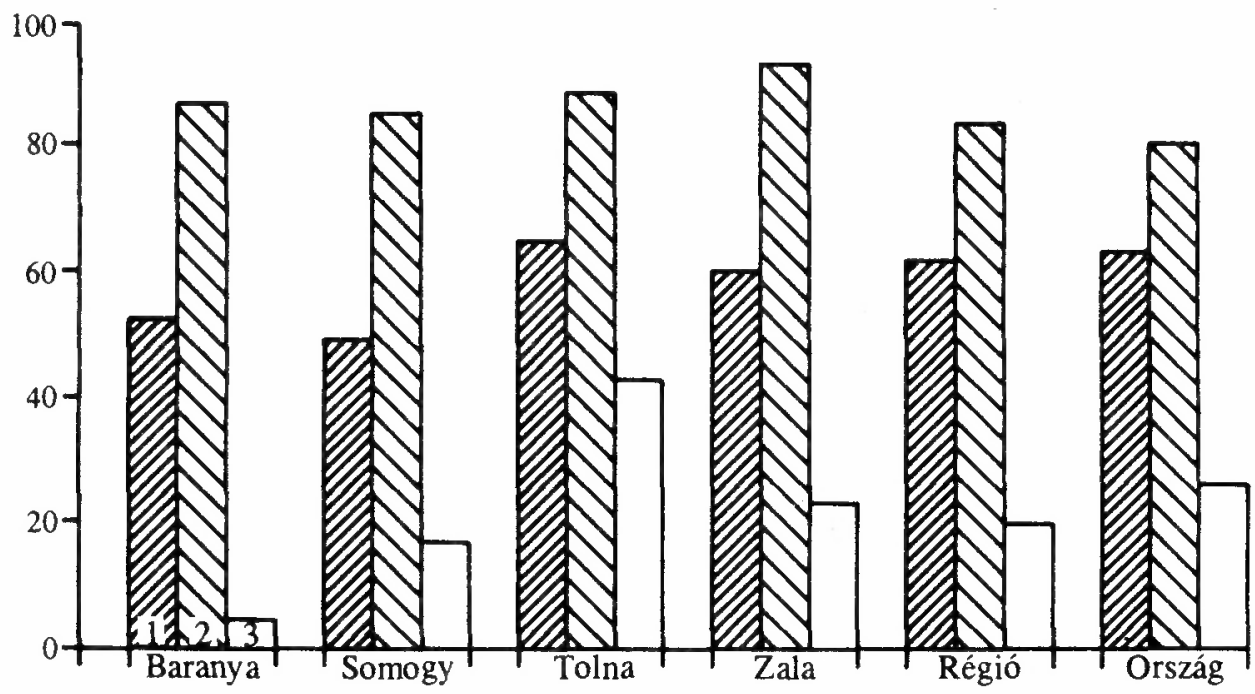

Jelmagyarázat: 1 - összes, 2 - városok, 3 - községek. 
A községek egyértelmũen hátrányos ellátottsága mellett további környezetvédelmi problémát jelent a talajt, talajvizeket szennyezõ legális vagy illegális lerakók nagy száma és gondozatlansága is. A kistelepüléseknek ilyen formán még csak reményük sincs a közeljövõben a hulladékkezelés szakszerü megoldására. A fejletlen infrastruktúrából következổen természeti környezetünk egyik legnagyobb veszélyhordozója e megoldatlan probléma. Csak súlyosbítja a konfliktushelyzetet, hogy ezek a szakszerútlen hulladékgyũjtố helyek 1982 elốtt potenciális tározóhelyei lehettek a veszélyes - ipari, olajos stb. - hulladékoknak. Így ezeknek a lerakóknak egy része a jövô század , ,idôzített bombája"' lehet.

Az igazi konfliktusforrásokat azonban az ún. regionális veszélyes hulladéklerakók, illetve kezelöhelyek jelentik. A Garé térségében $\mathrm{kb}$. 15 éve létesített regionális veszélyeshulladék-lerakó az 1990-es évek elejére a lakosság egészségét is fenyegetố, igazi veszélyforrássá vált. A Budapesti Vegyimũvek itt a növényvédôszer gyártásból keletkezô kb. 15500 tonna halogéntartalmú (klórozott) szénhidrogént tartalmazó hulladékot tárol kb. 60000 vashordóban. A vashordók idôvel korrodálódtak, veszélyes tartalmuk pedig minden irányban elszivárog - részben a talajvízzel -, de már a levegốkörnyezetet is elviselhetetlenül szennyezi.

Nehéz ilyen esetekben megoldást találni, mert a végleges ártalmatlanitást jelentõ veszélyeshulladék-égetố létesítése a környezố települések tiltakozó mozgalmait váltja ki, mint ahogy országos ellenállásba ütközött az ófalui radioaktív hulladéklerakó létesitése is. Csupán a dél-dunántúli régió két megyéjében (Somogy és Baranya) több mint 68000 tonna veszélyeshulladék keletkezik évente, amelynek kb. kétharmada vágóhídi és bốrgyári hulladék. Ma ezek nem csupán regionális szinten okoznak súlyos konfliktusokat, de országos léptékben sem kezelhetố egyelôre a veszélyeshulladékok problémája. $\mathrm{Az}$ átmeneti hulladéktározók viszont csak ideiglenes megoldást jelenthetnek. Az egyetlen végleges megoldás a hulladékok újrahasznosítása, illetve ártalmatlanítása lehet. A problémák társadalmi közmegegyezéssel történố kezelését rendkívül megnehezíti a környezeti tudat igen alacsony volta Magyarországon. Pedig tudni kell, hogy a különleges kezelést igénylõ veszélyes hulladékok még sokáig gondot fognak jelenteni.

Ezek a megállapítások azt igazolják, hogy a térség jövendố gazdaságfejlesztésének legsúlyosabb környezeti fékjét a hulladékkezelés megoldatlansága jelenti.

Mindezek érzékeltetik, hogy a térség infrastruktúrájának, elláááának fejlesztésénél a települési szilárd hulladékok gyưjjtése, kezelése, ártalmatlanítása a továbbiakban már nem kezelhetố az eddig követett ,,maradék elv" alapján. Végsố megoldást kell találni a ma már rendelkezésre álló rendszerszerũen mũködtethetố technológiák segítségével. 
Fodor István: A dél-dunántúli régió környezeti állapota a gazdaságfejlesztési stratégia egyik eleme.

Tér és Társadalom, 8. 1994. 1-2. 129-142. p.

138 Fodor István

TÉT $1994-1-2$

Az energia és energiahordozók kommunális felhasználása

Az 1950-es évek óta felfejlesztett magyar gazdaság közismert nyersanyag- és energiapazarló voltából adódóan a kommunális felhasználást sem korlátozták a gazdasági szabályozók, mint ahogyan környezetvédelmi megfontolások sem. Ma már tudományosan is igazolt, hogy az energia ilyen pazarlásának nem csak gazdasági okokból, de környezetvédelmi szempontból is véget kell vetni. Az energiaigény és az energiaforrások struktúrájának dinamikus átalakulása a területi felhasználásban is lényeges változásokat kell, hogy eredményezzen.

A nemzetközi összehasonlításból kiderül, hogy Magyarországon a fajlagos energiafelhasználás értékei - az ipar kivételével - még a kelet-közép-európai átlagnál is rosszabbak (2. táblázat).

\section{TÁBLÁZAT}

Magyarország fajlagos energiafelhasználási értékei a fejlett és kevésbé fejlett országok gazdaságával összehasonlítva (1985)

(Specific use of energy indices in Hungary compared to economies of developed and less developed countries [1985])

\begin{tabular}{lccccc}
\hline & \multicolumn{1}{c}{ Ipar } & & Közlekedés & & Háztartás \\
\cline { 2 - 3 } & ${ }^{*}$ PJ/millió DEM & & PJ/millió DEM & & TJ/fó/év \\
\hline Magyarország & 2,71 & & 1,26 & 37 \\
Kelet-Közép-Európa & 4,50 & & 1,20 & 34 \\
Nyugat-Európa & 1,35 & & 1,07 & 34 \\
\hline
\end{tabular}

*PJ/millió DEM a márkában kifejezett bruttó nemzeti termék.

Az adatok bár 1985-bốl származóak, mégis jól érzékeltetik a felhasználásbeli különbségeket, $\mathrm{s}$ becsülhetôen az eltelt idỗ alatt a különbség tovább nốtt a hátrányunkra.

Az energia és energiahordozók kommunális felhasználásának belsố struktúráját a fütési módok elemzésével tárjuk fel. A régióban csak a Pécsi Hổerômun Rt. üzemeltet erômũveket (Pécs, Komló), amelyek csak a szükebben vett környezetük villamos energia, távhổ és melegvíz ellátását oldják meg. A városokban rendszerint csak hôenergiát és melegvizet szolgáltató fütổmũvek üzemelnek, amelyek döntôen pakuratüzelésũek. Ha a régióban a távhỗvel és vezetékes gázzal ellátott lakások számát egymáshoz viszonyítjuk, kitủnik, hogy a közel 1,5 millió lakásból a távhôvel ellátottak alig 60 ezret tesznek ki. Ebbôl Pécsett közel 30 ezer távfũtött lakás található, a többi pedig a régió városait látja el. Az is szembetûnố, hogy Pécsett a vezetékes gázellátás kevésbé jellemzô a lakásokban, ez inkább Somogy és Zala városainak sajátossága. A régió egészében az egyedi 
Fodor István: A dél-dunántúli régió környezeti állapota a gazdaságfejlesztési stratégia egyik eleme. Tér és Társadalom, 8. 1994. 1-2. 129-142. p.

TÉT 1994-1-2

A dél-dunántúli régió környezeti állapota...

139

olaj- és széntüzelés a meghatározó, amely jelentôs forrása a városok légszennyezésének is.

Ezek az összefüggések azért érdemelnek figyelmet, mert a térség infrastrukturális ellátottságának javítása az életminôség szempontjából elengedhetetlen. Ennek egyik alapvetô eleme a rossz hatékonyságú, többnyire széntüzeléssel üzemeitetett egyedi hốellátó rendszerek kiváltása olaj- vagy méginkább gáztüzelésũ készülékekkel. Ez viszont azzal jár, hogy az adott térségben a lecsökkenô kén-dioxid szennyezettséget felváltja a nitrogénoxid szennyezettség, amelynek csökkentése kiemelt program Európában. A jármũforgalomból eredô kibocsátások mellett így éppen a lakossági fũtés válhat a fỗ nitrogénoxid forrássá, ami magyarázza a városokban már ma is növekvô, a levegốben télen-nyáron egyaránt mérhetô magasabb NO koncentrációkat.

Mindez azt érzékelteti, hogy a fưtési eredetû́ energiahordozó felhasználás mérséklésében a mủszaki beavatkozások alkalmazásának, készülékek elterjesztésének komoly lehetôségei vannak. A kevesebb energiahordozó felhasználása kevesebb légszennyezô anyag kibocsátásával is jár, ami a régió környezetminôségének javítása, megốrzése szempontjából igen fontos.

\section{A regionális környezetvédelmi politika hatékonyságának dilemmái}

A dél-dunántúli régió környezetminôségének elemzése alapján arra következtethetünk, hogy a térséget - környezeti konfliktusai ellenére - Magyarország kevésbé szennyezett területeihez sorolhatjuk. Ez a kedvezõ adottság a régiót olyan új fejlesztési stratégiák befogadására is alkalmassá teszi, amelyek felgyorsíthatják a szerkezetátalakítás folyamatát, serkenthetik gazdasági fellendülését.

Ehhez azonban olyan hatékony regionális környezetpolitika kialakítására és érvényesítésére van szükség, amely meghatározza a térség környezetvédelmi prioritásait, a preventív kömyezetpolitikai stratégiák kialakítását, emellett képes menedzselni annak megvalósítását, valamint alkalmas hatékony és elkerülhetetlen kömyezetvédelmi beavatkozásokra, egészen a veszélyforrások felszámolásáig.

A termelés mennyiségi fejlesztését forszírozó régi gazdasági rendszerben alig múködhettek ellenerôk a kömyezetet szennyezô technika és technológia alkalmazásával szemben. Ugyanakkor kevés intézmény kapott tényleges törvényi felhatalmazást a kömyezet hatékony védelmére.

Az ipar sokkszerũen bekövetkezett és egyre mélyülõ strukturális válsága számos olyan vállalat egzisztenciáját rendítette meg, amely a korábbiakban fokozottan szennyezônek számított. Az ipar mennyiségi favorizálásának kudarca a termelés jelentôs csökkenésében, valamint vállalatok megszunnésében egyaránt kifejezésre jut. A mennyiségi fejlesztés meggyengülése az output számottevố csökkenésén keresztül az emisszió mérséklốdését eredményezi. A regionális környezetvédelmi koncepció készítôinek abból kell kiin- 
dulniuk, hogy az új helyzetben a környezetvédelmi szempontok elôtérbe kerülhetnek és minden korábbinál hatékonyabban érvényesíthetốk lesznek.

A bányászat, az alapanyagtermelô iparok és a jelentôs szennyezéssel járó feldolgozóipar számos üzeme vagy bezárásra kerül, vagy jelentôs mértékũ visszafejlesztésre. Ilyen helyzetben arra kell felkészülni, hogy milyen eszközökkel kezelhetõ a megszünés és leépítés utáni állapot. Amennyire sok termelési, munkaerôgazdálkodási, szociális és politikai probléma forrása az ipar fejlôdésének lelassulása, annyira kedvezõ hatású környezetvédelmi szempontból. Az ipari visszaesésnek nyilvánvalóan nem szándékolt ,,mellékterméke" a környezeti terheltség enyhülése, mégis kézzelfogható eredménye.

Az ipari struktúrák hanyatlása ugyanakkor egy nagyon veszélyes vákuumhelyzetet is elôidéz. A veszély lényege abban áll, hogy az ipari üzemek bezárása nyomán keletkezô munkanélküliség felszámolása érdekében esetleg nem válogatnak az eszközökben. A külföldrôl beáramló mũködố tốke egyik fontos jellemzõje, hogy a Közép-Kelet-Európa gazdaságaiba transzferált technika és technológia gyakran másodosztályú, azaz környezetszennyezó. Bármennyire is fontosnak tartjuk az új munkahelyek létesítését, a mũködố tôke bejövetelét, a technológia transzfert, semmilyen körülmények között sem engedhetünk a környezetvédelmi elôirásokból. Egy újonnan kidolgozásra kerülõ koncepcióban megkülönböztetett jelentôséget kell tulajdonítani annak a törekvésnek, hogy sem a régió, sem az ország ne váljék a fejlett technológiájú országok környezetszennyezési hátsó udvarává.

A napjainkban széles körben folyó tulajdonosváltás, amelynek legeklatánsabb megnyilvánulása a privatizáció, szintén számos ponton érintkezik környezetvédelni megfontolásokkal. A térség, a régió, vagy a megye környezetvédelméér felelôs intézmények és testületek a korábbiaknál hatékonyabb módon léphetnek fel az immár jól definiálható tulajdonossal szemben a környezetet károsító hatások felszámolása érdekében. Korábban az államnak az állami tulajdonban levố vállalatokkal szemben kellett volna fellépnie, ami az esetek többségében igazán nem lehetett sikeres. Az új tulajdonosi helyzetben erre több eszköz, kedvezöbb jogi kömyezet és toleránsabb társadalmi közeg áll rendelkezésre.

$\mathrm{Az}$ is igaz azonban, hogy a klasszikus közgazdaságtan alapelvein megfogalmazott modernizációs törekvések mindeddig hatástalanok voltak, vagy legalábbis a környezetvédelmi ráfordításokhoz viszonyítottan a kömyezetvédelemben aránytalanul kis hatékonyságot eredményeztek. Számomra úgy tũnik, hogy e dilemma áttörésének, egy hosszú távon megvalósítható gazdasági fejlesztési stratégia sikerének csak akkor van esélye, ha a közgazdasági gondolkodás megérti, hogy a világgazdaság csupán egy alrendszere a globális ökológiai rendszernek, és ezt egyaránt érvényesíti nemzetgazdasági, regionális és helyi önkormányzati szinten. Ez teljesen újfajta öko-gazdasági modellek kidolgozását és mũködtetését teszi szükségessé regionális és önkormányzati szinten. Egyszerũen azért, mert ezek azok a társadalmi, gazdasági és természeti térbeli dimenziók, amelyek a legmozgékonyabbak és leghatékonyabban válaszolhatnak az egyre sú- 
Fodor István: A dél-dunántúli régió környezeti állapota a gazdaságfejlesztési stratégia egyik eleme. Tér és Társadalom, 8. 1994. 1-2. 129-142. p.

TÉT $1994 \square 1-2$

A dél-dunântúli régió környezeti állapota...

141

lyosabbá váló környezeti válság kihívásaira. Ma még bármilyen kicsiny is ennek az esélye, más kiút a fenntartható fejlōdés irányába aligha található (Feladatok a XXI. századra, 1993).

\section{Irodalom}

Adatok Magyarország levegốtisztaság-védelmérổl. KTM, Budapest, 1992, 30 o.

Aktuális adatok a levegôtisztaság-védelemrôl. KTM Kömyezetvédelmi Hivatalának Levegõtisztaság-védelmi és Zajellenôrzési Fôosztálya, Budapest, 1993, 6 o. 14 táblázat, 21 ábra.

A Dél-Dunántúl területfejlesztési koncepciója. (Témavezetô: Faragó L.) Készült a KTM megbízásából. MTA RKK DTI, Pécs, 1994.

Enyedi Gy. (szerk.) (1993) Társadalmi-területi egyenlôtlenségek Magyarországon. Közgazdasági és Jogi Könyvkiadó, Budapest.

Enyedi Gy. - Tamási P. (1992) Kömyezeti problémák - társadalmi változások. - INFO-Társadalomtudomány, 3-5. o.

Feladatok a XXI. századra. - Az ENSZ Környezet és Fejlödés Világkonferencia dokumentumai. Budapest, 1993. 4330 .

Fodor I. - Schubert J. (szerk.) (1991) Adatok Baranya megye kömyezetvédelméröl, természetvédelmérôl és vízgazdálkodásáról. MTA Pécsi Akadémiai Bizottság, Pécs, 193 o.

Fodor I. - Schuben J. (szerk.) (I991) Adatok Somogy megye környezetvédelmérôl, természetvédelmérõl és vízgazdálkodásáról. MTA Pécsi Akadémiai Bizottság, Pécs, 2290.

Fodor 1.-Orosz T. (1994) Az önkormányzatok életképességét befolyásoló kömyezeti tényezők. In: Tér és Közigazgatás. (Szerk.: Csefkó F.) MTA RKK - MKI, Pécs, 243-256. o.

Horváth Gy. (1992) A magyar regionális politika súlypontjai. Tér és Társadalom, 6. 1-15. o.

Magyarország szennyezett levegôjũ területei. 1994. A Kornány 1079/1993. (XII. 23.) Kormányhatározata Mellékletének 9. pontja. Kiad. a Kömyezetvédelmi és Területfejlesztési Miniszter, Népjóléti miniszter. 1-6. 0 .

Sebestyén Gy. (1990) Kömyezet, energia, épités. Környezet és Fejlödés, 7. 27-31. o.

Tóth J. (1992) Regionális folyamatok Magyarországon. In: Régió, válságtérségek, törvényhozás. (Szerk.: Székely G. - Wéber A.) Politikatörténeti Alapítvány, Budapest, 21-30. o.

\section{THE STATE OF ENVIRONMENT IN THE SOUTHERN TRANSDANUBIAN REGION IS AN ELEMENT OF THE ECONOMIC DEVELOPMENT STRATEGY}

\section{ISTVÁN FODOR}

The modernisation efforts expressed on the basic principles of the classic economics have been ineffective so far, or have resulted in an unproportionately weak effect compared to the costs in environmental protection. It seems that a long term economic development strategy has got chances of breaking through this dilemma only if the 
economic thinking comprehends that the world economy is only a sub-system of the global ecological system, and this is considered at national economic, regional and local self governmental levels. This makes the completion and functioning of new ecoeconomic models necessary at regional and self governmental levels. The reason for this is the fact that these are the social, economic and natural spatial dimensions that are the most mobile and can react in the most effective ways to the challenges of the deepening environmental crisis. However slight the chance for that is for the time being, there can hardly be any other way out towards sustainable development.

The author analyses the state of the environment of Southern Transdanubia, as an important element of the economic development strategy of the region, in this spirit.

With the exception of some industrialised regions of Southern Transdanubia, it is just the belatedness, or the lack of the industrial development that spared the environment of a large part of the region from serious ecological degradation. Still Southern Transdanubia is not free from environmental conflicts, either. Already there are several local issues that cannot be solved from local resources, alone. These are discussed in detail in the study. In order to deal with the most significant environmental problems, it would be necessary to create regional resources, but if the region lacks them, even the solution of region conflicts must be financed from the national level (e. g. the treatment and neutralising of dangerous waste products generated or stored in the region). The want of these can be a serious hindrance to the economic development strategies.

Translated by Zoltán Raffay 